\title{
DNA DAMAGE IN HOMOCYSTINURIA: 8-OXO-,8-DIHYDRO-2'-DEOXYGUANOSINE LEVELS IN CYSTATHIONINE-B-SYNTHASE DEFICIENT PATIENTS AND THE IN VITRO PROTECTIVE EFFECT OF N-ACETYL-L-CYSTEINE
}

\begin{abstract}
Camila Simioni Vanzin ${ }^{1,2}$, Caroline Paula Mescka², Bruna Donida ${ }^{1}$, Desirèe Padilha Marchetti ${ }^{1}$, Carlos Eduardo Jacques ${ }^{1}$, Tatiane Hauschild ${ }^{3}$, Jéssica Lamberty Faverzani ${ }^{2}$, Marion Deon ${ }^{3}$, Dinara Jaqueline Moura ${ }^{4}$, Jenifer Saffi ${ }^{4}$, Daniella de Moura Coelho ${ }^{2}$, Moacir Wajner ${ }^{1,2}$, Angela Terezinha de Souza Wyse ${ }^{1}$, Carmen Regla Vargas ${ }^{1,2,3}$
\end{abstract}

\section{ABSTRACT}

Clin Biomed Res. 2018;38(1):50-57

1 Postgraduate Program in Biological Sciences: Biochemistry, Universidade Federal do Rio Grande do Sul (UFRGS). Porto Alegre, RS, Brasil.

2 Medical Genetics Service, Hospital de Clínicas de Porto Alegre (HCPA). Porto Alegre, RS, Brasil.

3 Postgraduate Program in Pharmaceutical Sciences, Universidade Federal do Rio Grande do Sul (UFRGS). Porto Alegre, RS, Brasil.

4 Laboratory of Toxicological Genetics, Universidade Federal de Ciências de Saúde de Porto Alegre (UFCSPA). Porto Alegre, RS, Brasil.

Corresponding author: Carmen Regla Vargas crvargas@hcpa.edu.br Serviço de Genética Médica, Hospital de Clínicas de Porto Alegre (HCPA) Rua Ramiro Barcelos, 2350 90035-903, Porto Alegre, RS, Brasil.
Introduction: Homocysteine (Hcy) tissue accumulation occurs in a metabolic disease characterized biochemically by cystathionine $\beta$-synthase (CBS) deficiency and clinically by mental retardation, vascular problems, and skeletal abnormalities. Previous studies indicate the occurrence of DNA damage secondary to hyperhomocysteinemia and it was observed that DNA damage occurs in leukocytes from CBS-deficient patients. This study aimed to investigate whether an oxidative mechanism could be involved in DNA damage previously found and investigated the in vitro effect of $\mathrm{N}$-acety-L-cysteine (NAC) on DNA damage caused by high Hcy levels.

Methods: We evaluated a biomarker of oxidative DNA damage in the urine of CBS-deficient patients, as well as the in vitro effect of NAC on DNA damage caused by high levels of Hcy. Moreover, a biomarker of lipid oxidative damage was also measured in urine of CBS deficient patients.

Results: There was an increase in parameters of DNA (8-oxo-7,8-dihydro-2'deoxyguanosine) and lipid (15-F2t-isoprostanes levels) oxidative damage in CBS-deficient patients when compared to controls. In addition, a significant positive correlation was found between 15-F2t-isoprostanes levels and total Hcy concentrations. Besides, an in vitro protective effect of NAC at concentrations of 1 and $5 \mathrm{mM}$ was observed on DNA damage caused by Hcy $50 \mu \mathrm{M}$ and $200 \mu \mathrm{M}$. Additionally, we showed a decrease in sulfhydryl content in plasma from CBS-deficient patients when compared to controls.

Discussion: These results demonstrated that DNA damage occurs by an oxidative mechanism in CBS deficiency together with lipid oxidative damage, highlighting the NAC beneficial action upon DNA oxidative process, contributing with a new treatment perspective of the patients affected by classic homocystinuria.

Keywords: Cystathionine- $\beta$-synthase deficiency; oxidative stress; 8-oxo-7,8-dihydro2'-deoxyguanosine; homocysteine; DNA damage; N-acetyl-L-cysteine

Cystathionine beta synthase (CBS) deficiency (classic homocystinuria) is biochemically characterized by elevated levels of circulating homocysteine (Hcy) and methionine, S-adenosylmethionine and S-adenosyl homocysteine, as well as reduced circulating levels of cystathionine and cysteine ${ }^{1}$. CBS deficiency has an estimated worldwide incidence of 1:344,000 live births and has autosomal recessive inheritance ${ }^{2}$. 
Some patients affected by classic homocystinuria have small residual CBS activity, whereas other patients with CBS deficiency have no such enzyme activity detected by even the most sensitive methods ${ }^{1}$. The eye, skeleton, central nervous system, and vascular system are all involved in the typical presentation. The patient is normal at birth and, if not treated, progressively develops the full clinical picture $^{3}$. The recommended treatment modalities for this disease include pyridoxine in combination with folic acid and/or $\mathrm{B}_{12}$ vitamin and/or betaine, as well as methionine-restricted diet supplemented with cysteine ${ }^{2}$. Probably, both early diagnosis and strict compliance to treatment will change the natural history of cardiovascular and mental symptoms even in pyridoxine-nonresponsive individuals. Although various mechanisms have been proposed to explain the pathophysiology of CBS deficiency, this issue has not been completely elucidated. However, accumulation of total homocysteine (tHcy) probably plays a major role in determining some of the most relevant clinical manifestations, particularly generalized vascular damage and thromboembolic complications in patients affected by CBS deficiency ${ }^{3}$. In a recent study, we have demonstrated the importance of $B_{12}$ vitamin in some biochemical parameters and of folic acid in reducing plasma tHcy levels in CBS-deficient patients ${ }^{4}$.

Hcy is a sulphydryl amino acid that oxides readily to its disulphide form (homocystine). In normal plasma, Hcy exists in various forms: the sulphydryl form (approximately 1\%), bound to the cysteine residues of proteins (approximately $70 \%$ ), and bound to free cysteine as cysteine-Hcy mixed disulphide (approximately $30 \%$ ). When Hcy levels are elevated, its disulphide form (homocystine) is formed. Homocystine renal tubular reabsorption is very inefficient in patients with severe untreated CBS deficiency and more than $1 \mathrm{mmol}$ of this disulfide may be excreted each day ${ }^{1}$. Normal plasma tHcy values are less than $15 \mu \mathrm{mol} / \mathrm{L}$, whereas most untreated CBS-deficient patients exhibit levels above $200 \mu \mathrm{mol} / \mathrm{L}$. In plasma, tHcy is the sum of free and protein-bound homocysteine, homocystine, and several other mixed disulfides ${ }^{3}$.

Free radicals and other reactive species are widely believed to contribute to the development of several diseases ${ }^{5,6}$. In what concerns homocystinuria, some studies performed in animal models showed the involvement of oxidative stress ${ }^{7,8}$ and some reports described oxidative damage induced by Hcy and Hcy thiolactone in neurons and in HL-60 cells, respectively ${ }^{9,10}$. Moreover, it was previously demonstrated that lipid and protein oxidative damage are increased and antioxidant defenses are decreased in plasma of CBS-deficient patients, probably due an increase of reactive species generation induced by $\mathrm{tHcy}^{11}$.
Besides, it was observed that DNA damage occurs in leukocytes from CBS-deficient patients, but it was not investigated whether the mechanism that induced damage had an oxidative origin ${ }^{12}$.

Guanine is the nucleobase most prone to oxidation, and 8-oxo-7,8-dihydro-2'-deoxyguanosine (from DNA) is the form of oxidized guanine that is most commonly studied. In recent years, it has been shown that both DNA and RNA are damaged by oxidation in disease states, and that repair processes which are initiated to correct this damage lead to a release of multiple oxidized guanine species into the urine, including the ribose-free base (8-oxo-guanine or 8-hydroxyguanine), the nucleoside from RNA (8-oxo-7,8-dihydroguanosine), and the deoxynucleoside from DNA (8-oxo-7,8-dihydro-2'-deoxyguanosine) ${ }^{13}$.

The thiol $\mathrm{N}$-acetyl-L-cysteine (NAC) is an antioxidant that is readily deacetylated in cells to yield L-cysteine, thereby promoting intracellular reduced glutathione (GSH) synthesis. Reduced glutathione plays a central physiological role in maintaining body homeostasis and in protecting cells against oxidants, toxicants, DNA-damaging agents, and carcinogens of either exogenous or endogenous source. Besides, acting as a GSH precursor, NAC is, per se, responsible for protective effects in the extracellular environment, mainly due to its nucleophilic and antioxidant properties ${ }^{14}$.

Considering the points raised above, this study aimed to evaluate the urinary biomarker of oxidative damage to DNA (8-oxo-7,8-dihydro-2'-deoxyguanosine), as well as lipid peroxidation marker (15-F2t-isoprostane) in urine from CBS-deficient patients to investigate whether an oxidative mechanism could be involved in DNA damage. We also assessed the in vitro effect of NAC on DNA damage caused by high Hcy levels.

\section{METHODS}

\section{In vivo Study}

\section{Patients and controls}

Occasional urine and blood samples were collected from 11 CBS-deficient patients (median age: 17 years; range: 11-33 years). All of them received treatment with supplementation of pyridoxine (median dose: $500 \mathrm{mg} /$ day; range: $100-750 \mathrm{mg} /$ day), folic acid (median dose: $5 \mathrm{mg} /$ day; range $2-5 \mathrm{mg} /$ day), betaine (median dose: $6 \mathrm{~g} /$ day; range: $2-6 \mathrm{~g} /$ day) and vitamin $B_{12}$ (median dose: $1 \mathrm{mg} /$ month, intramuscularly), in addition to a protein-restricted diet. The mean time on treatment was 13 years (range: 1-22 years) and the average plasmatic levels of tHcy in those patients was $191.3 \pm 105.3 \mu \mathrm{mol} / \mathrm{L}$ (mean \pm standard deviation).

CBS-deficient homocystinuric patients enrolled in this study were being followed-up in the Service of Medical Genetics of Hospital de Clínicas de Porto Alegre, 
Brazil. Patients' diagnosis was made by the abnormal concentrations of tHcy and methionine identified in plasma. Predominantly, clinical presentations were characterized by neuropsychomotor alterations - such as developmental delay and seizures -, ectopia lentis, and a marfanoid appearance (lengthening and thinning of long bones).

For the control group, samples from nine healthy age- and sex-matched individuals (median age: 22 years; range: 15-30 years) were collected. These individuals were recruited from the Laboratory of Clinical Analyses da Universidade Federal do Rio Grande do Sul.

This study was approved by the Ethics Committee of Hospital de Clínicas de Porto Alegre, Brazil, and registered under the number 10-0290. Written informed consent was obtained from all patients and healthy individuals participating in the study, according to the Ethics Committee guidelines.

\section{Urine collection}

Occasional urine samples were obtained from individuals (controls and CBS-deficient patients) and frozen at $-80^{\circ} \mathrm{C}$ until analysis.

\section{Blood collection}

Blood samples were collected from healthy individuals and CBS-deficient patients into heparinized tubes by venous puncture. Whole blood was centrifuged at $3,000 \times \mathrm{g}$ for $10 \mathrm{~min}$ at $4^{\circ} \mathrm{C}$, and the clear plasma was aspirated, aliquoted and kept frozen $\left(-80^{\circ} \mathrm{C}\right)$ until analysis.

\section{8-oxo-7,8-dihydro-2'-deoxyguanosine (8-oxodG)}

Urinary 8-hydroxy-2'-deoxyguanosine (from DNA), 8- hydroxyguanosine (from RNA) and 8-hydroxyguanine (from DNA and RNA) levels were determined by the DNA/RNA oxidative damage enzyme-linked immunoassay (ELISA) kit (Cayman Chemical, USA). This urinary assay is based on a competitive in vitro enzyme-linked immunosorbent assay between oxidatively damaged guanine species and an 8-OH-dG-acetylcholinesterase conjugate (DNA/RNA oxidative damage tracer) for a limited about of DNA/RNA oxidative damage monoclonal antibody. Results were expressed as ng per mg urinary creatinine.

\section{5-F2t-isoprostane determination}

15-F2t-isoprostane was measured by a competitive ELISA between the 15-F2t-isoprostane in the sample and the 15-F2t-isoprostane conjugated to horseradish peroxidase (HRP) for binding to a specific polyclonal antibody fixed on the microplate (Oxford Biomed,
EA 85). The concentration of 15-F2t-isoprostane was determined by the intensity of color developed after the addition of substrate (wavelength at $630 \mathrm{~nm}$ ) and was reported as nanograms of isoprostanes per $\mathrm{mg}$ urinary creatinine.

\section{Urine creatinine determination}

Urine creatinine determination was performed by a picric acid method (kit by Labtest Diagnóstica, Minas Gerais, Brazil). The concentrations were represented as $\mathrm{mg} / \mathrm{dL}$.

\section{Total homocysteine (tHcy) measurement}

Total homocysteine levels in plasma, the sum of free and protein-bound homocysteine, homocystine, and several other mixed disulfides were measured by liquid chromatography electrospray tandem mass spectrometry (LC-MS/MS), as described by Magera et al. ${ }^{15}$. The results were expressed as $\mu \mathrm{mol} / \mathrm{L}$.

\section{Sulfhydryl content measurement}

Thirty microliters of 5.5'-dithio-bis (2-nitrobenzoic acid) (DTNB) were incubated with an equal volume of plasma at room temperature for 30 minutes in a dark room. The reduction of DTNB by thiols produces a yellow derivative (2-nitro-5-thiobenzoate - TNB) whose absorption is measured spectrophotometrically $(412 \mathrm{~nm})^{16}$. The sulfhydryl content is inversely correlated to oxidative damage to proteins and was reported as nmol TNB/mg protein.

\section{In vitro study}

Venous blood from five healthy volunteers individuals was collected under sterile conditions into heparinized tubes. Whole blood cells from each subject were incubated without Hcy and NAC (control group), with different concentration of Hcy (50 and $200 \mu \mathrm{M})$, and in a co-treatment with Hcy (50 and $200 \mu \mathrm{M}$ ) and NAC (1 and $5 \mathrm{mM}$ ) for $6 \mathrm{~h}$ at $37^{\circ} \mathrm{C} 17,18$. The Hcy concentrations were based on levels found in blood from treated CBS-deficient patients, since the CBS-deficient patients who have good treatment adherence present $\mathrm{tHcy}$ levels around $50 \mu \mathrm{M}$, and the individuals who do not have good treatment adherence present tHcy levels around $200 \mu \mathrm{M}^{1}$.

\section{Single cell gel electrophoresis (comet assay)}

The alkaline comet assay was carried out as described by Singh et al. ${ }^{19}$ in conformity with the general guidelines for use of the comet assay ${ }^{17,18}$. Aliquots of $100 \mu \mathrm{L}$ from whole blood previously incubated with or without Hcy and/or NAC were suspended in agarose and spread into a glass 
microscope slide pre-coated with agarose to perform the comet assay ${ }^{17-20}$. In each slide, 100 cells were microscopically analyzed and the damage class of each cell was determined. The damage classes were classified into: $0=$ no tail (no damage); $1=$ small tail (smaller than the diameter of the head); 2 = tail length between one and two times the diameter of the head; $3=$ long tail (greater than twice the diameter of the head); 4 = long tail and more widespread than class 3 . Subsequently, the number of cells found in each damage class was multiplied by the number of the corresponding class. The damage index (DI) was determined by the sum of these multiplications. The slides were analyzed under blind conditions at least by two different individuals.

\section{STATISTICAL ANALYSIS}

\section{In vivo Study}

All the analyses were performed using the Statistical Package for Social Sciences (SPSS) software. Results were expressed as mean \pm standard deviation and the comparison between means was analyzed by the Student's t test for unpaired samples. Correlations between variables were performed by Pearson correlation test. A $p$ value of less than 0.05 was considered significant.

\section{In vitro Study}

Comet assay data were expressed as mean \pm standard deviation and were calculated by one-way ANOVA followed by the Duncan post roc test, when the $F$ value was significant. A $p$ value lower than 0.05 was considered significant. All analyses were performed using the SPSS software.

\section{RESULTS}

The 8-oxo-7,8-dihydro-2'-deoxyguanosine levels were significantly higher in CBS-deficient patients when compared to controls $[t(12)=2.636, p<0.05]$, indicating DNA damage by an oxidative mechanism. Similarly, 15-F2t-isoprostanes levels, a parameter of oxidative damage to lipids, were significantly higher in CBS-deficient patients when compared to controls $[t(15)=2.458, p<0.05]$. We found a significant positive correlation between 15-F2t-isoprostanes levels and thcy levels $(r=0,780, p<0.05)$, indicating that Hcy seems to induce oxidative damage (Figure 1).

In this study, we also evaluated the in vitro effect of NAC on DNA damage caused by high levels of Hcy. We found a significantly higher DNA damage induced by 50 and $200 \mu \mathrm{M}$ of Hcy compared to the control group and observed that NAC at 1 and $5 \mathrm{mM}$ concentrations was able to significantly decrease the DNA damage caused by Hcy $50 \mu \mathrm{M}$ and
(A)

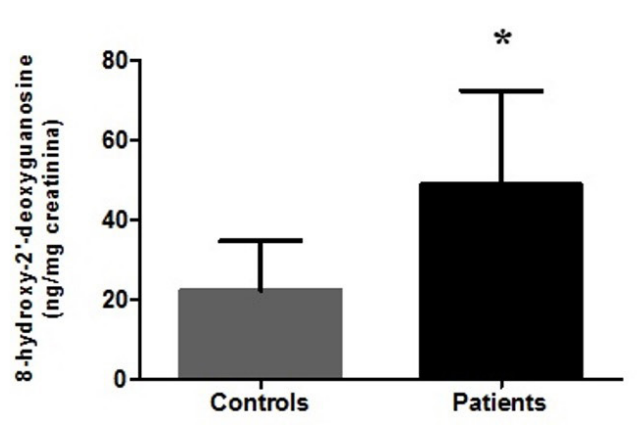

(B)

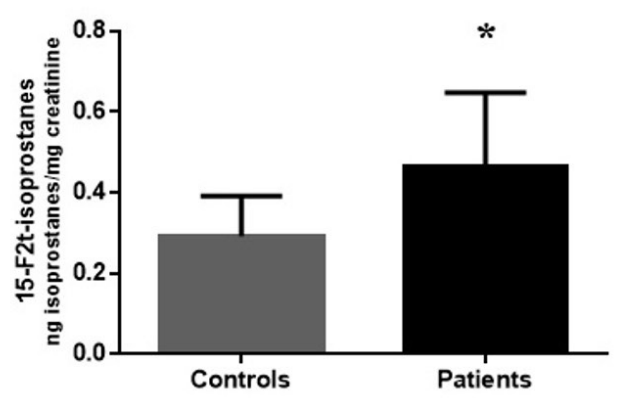

(C)

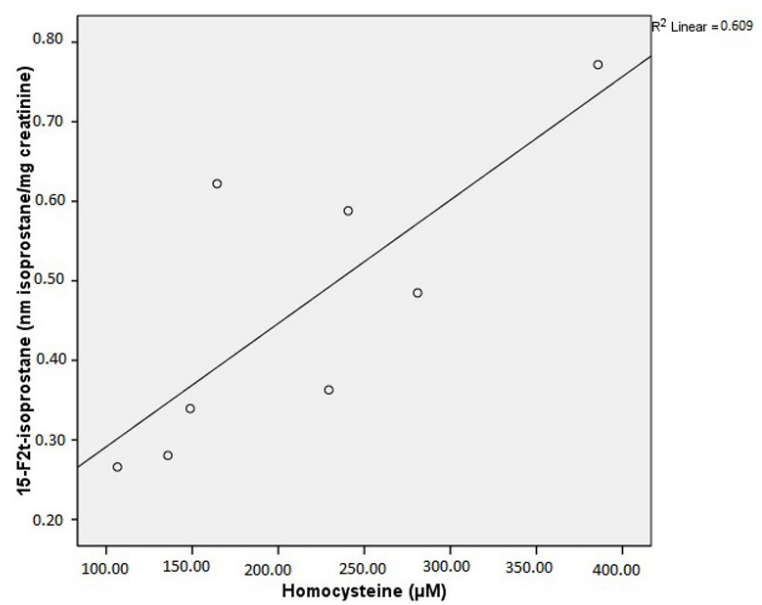

Figure 1: Oxidative damage to DNA [8-oxo-7,8-dihydro-2'deoxyguanosine levels (A)] and lipids [15-F2t-isoprostanes levels $(B)]$ in urine from CBS-deficient patients and controls. Data represent the mean \pm standard deviation (controls: $n=7-9$; patients: $n=7-9$ ). * $p<0.05$, compared to controls (Student's t test for unpaired samples). (C) Correlation between urinary 15-F2t-isoprostanes levels and plasma tHcy levels from CBS- deficient patients.

Hcy $200 \mu \mathrm{M}$ (Figure 2). Furthermore, we demonstrated that sulfhydryl content was significantly lower in plasma of CBS-deficient patients when compared to controls $[t(18)=2.370, p<0.05]$ (Figure 3$)$. 


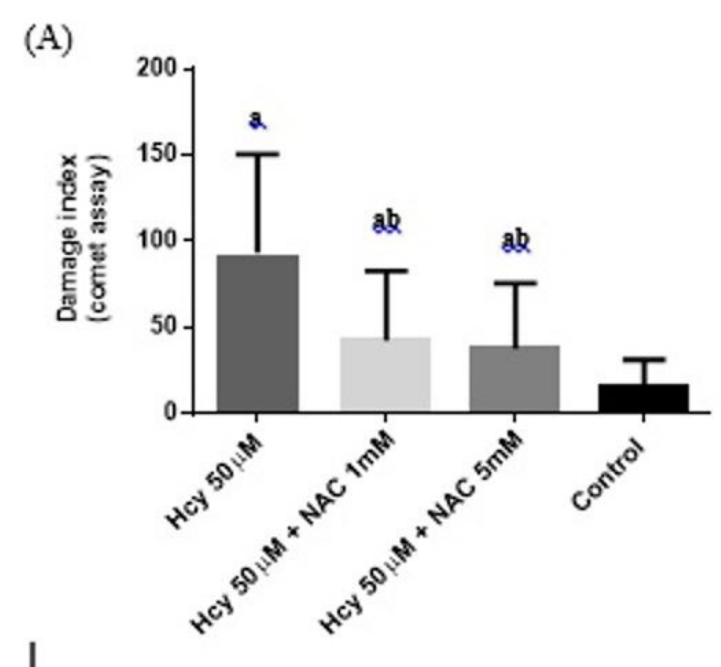

(B)

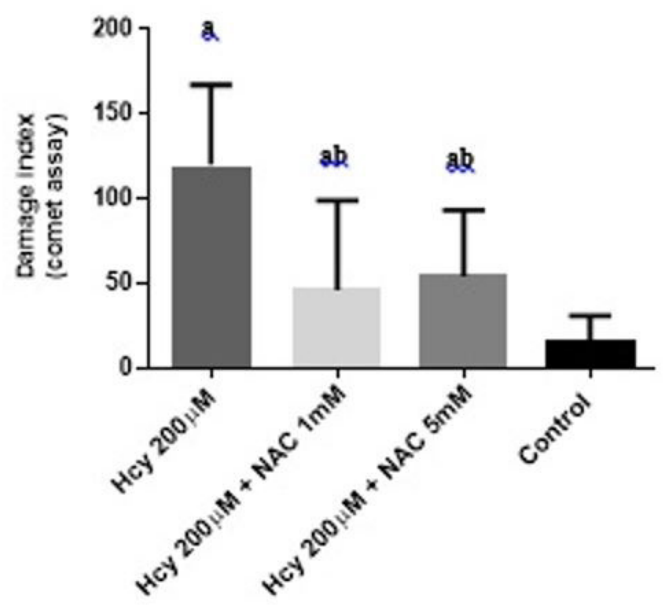

Figure 2: In vitro effect of NAC at 1 and $5 \mathrm{mM}$ concentrations on DNA damage caused by Hcy $50 \mu \mathrm{M}(\mathrm{A})$ and Hcy $200 \mu \mathrm{M}$ (B). Data represent the mean \pm standard deviation of three independent experiments. (a) $p<0.05$, compared to control (without Hcy and NAC), (b) $p<0.05$, compared to Hcy $50 \mu \mathrm{M}$ or Hcy $200 \mu \mathrm{M}$ (one-way ANOVA, followed by Duncan test).

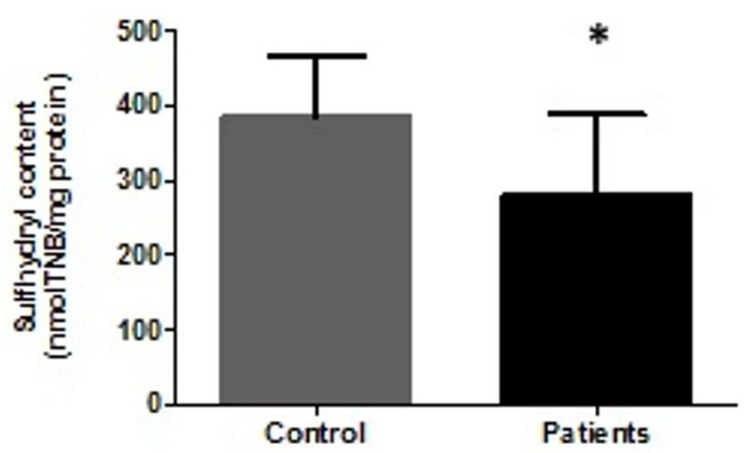

Figure 3: Sulfhydryl content in plasma from CBS-deficient patients and controls. Data represent the mean \pm standard deviation (controls: $n=9$; patients: $n=11$ ). ${ }^{*} p<0.05$, compared to controls (Student's t test for unpaired samples).

\section{DISCUSSION}

Oxidative stress has been related to the pathophysiology of various inborn errors of metabolism ${ }^{21}$. In this study, an important biomarker of oxidative DNA damage (8-oxodG) was investigated in urine samples from CBS-deficient patients. Moreover, we evaluated the in vitro effect of NAC on DNA damage induced by high Hcy concentrations. Isoprostanes, an urinary biomarker of lipid peroxidation, as well as sulfhydryl content, were also analyzed in CBS-deficient patients.

Recent studies indicate the occurrence of DNA damage secondary to hyperhomocysteinemia: Lin et al. ${ }^{22}$ demonstrated the synergic actions of Hcy and S-adenosylhomocysteine (SAH) on DNA damage in a murine microglial cell line through a mechanism involving reactive oxygen species (ROS), and Huang et al. ${ }^{10}$ showed that Hcy induces apoptotic DNA damage in HL-60 cells mediated by increased intracellular generation of $\mathrm{H}_{2} \mathrm{O}_{2}$. In the present study, by using urinary 8-oxodG measurement, we intended to investigate whether the DNA damage found in CBS-deficient patients is established by an oxidative mechanism. It was demonstrated that oxidative DNA damage occurs in CBS-deficient patients, since they presented a significant increase in urinary 8-oxodG levels compared to controls. Oxidative DNA damage results of the attack by ROS in both nuclear and mitochondrial DNA, producing predominantly an oxidized form of guanosine, the 8 -oxodG ${ }^{23}$. The oxidized DNA is continuously repaired, and the oxidized nucleoside is excreted into the bloodstream and into urine; 8-oxodG reflects the equilibrium between its production and repair in both DNA and the nucleotide pool ${ }^{24}$. 8 -oxodG is the most sensitive marker of oxidative DNA damage and reflects total systemic oxidative stress in vivo ${ }^{25}$. In addition, 8-oxodG is an established risk marker for atherosclerosis and diabetes mellitus and it has been shown that urinary 8 -oxodG is more stable than serum 8-oxodG ${ }^{26}$.

Considering the oxidative DNA damage found in CBS-deficient patients, we also evaluated the effect of NAC on DNA damage caused by 50 and $200 \mu \mathrm{M}$ concentrations of Hcy. NAC at 1 and $5 \mathrm{mM}$ concentrations was able to significantly reduce the damage caused by Hcy 50 and $200 \mu \mathrm{M}$, evidencing an antioxidant effect of that molecule. Studies provide evidence that NAC has antigenotoxic and anticarcinogenic properties in several experimental models ${ }^{27}$. As a source of sulfhydryl groups, which neutralize ROS, NAC plays a critical role in 
regulating the oxidant/antioxidant balance directly and in decreasing cell oxidative stress ${ }^{28}$. Since we demonstrated in this study that CBS-deficient patients have reduced sulfhydryl group levels, NAC supplementation could be beneficial during the treatment of this CBS deficiency. According to Ozdemir et al. ${ }^{29}$, NAC supplementation was able to reduce DNA damage in children with $\beta$-thalassemia. Yang et al. ${ }^{30}$ demonstrated by comet assay that incubation of cells with ochratoxin A (OTA) for $24 \mathrm{~h}$ resulted in DNA strand breaks and an evident comet tail. Pretreatment with NAC significantly inhibited OTA-induced DNA strand breaks and reduced the formation of comets. An in vitro study showed that NAC was able to reduce DNA damage in blood of patients with symptomatic X-linked adrenoleukodystrophy (X-ALD), suggesting that the administration of this antioxidant might be considered as an adjuvant therapy for X-ALD ${ }^{31}$.

Oxidative stress is characterized by an imbalance between reactive species and antioxidant defenses. Free radicals cause direct damage to critical biomolecules, including DNA, lipids, and proteins $^{23}$. Isoprostanes are prostaglandin (PG)-like compounds that are produced in vivo independently of cyclooxygenase enzymes, primarily by free radical-induced peroxidation of arachidonic acid ${ }^{32}$. Isoprostane measurement is the most reliable in vivo approach to assess lipid peroxidation, providing an important tool to explore the role of oxidative stress in the pathogenesis of diseases. This study demonstrated that CBS-deficient patients have increased urinary 15-F2t-isoprostanes levels. Moreover, a significant positive correlation was found between 15-F2t-isoprostanes and tHcy levels, suggesting that Hcy seems to induce oxidative damage in the affected patients. Homocysteine is readily oxidized in plasma, mainly as a consequence of auto-oxidation, leading to the formation of homocystine, homocysteine-mixed disulfides, and homocysteine thiolactone. It has been proposed that during the transition metal ion-catalyzed oxidation of the sulfhydryl group of Hcy, hydrogen peroxide is formed, which promotes oxidative stress and lipid peroxidation through Fenton-type reactions ${ }^{33,34}$. It is important to emphasize that the average tHcy plasma levels presented by the treated CBS-deficient patients of the present study was $191.3 \mu \mathrm{M}$, which is much higher than the tHcy plasma reference value (5-15 $\mu \mathrm{M})$, suggesting an inappropriate metabolic control of the patients. Davì et al. ${ }^{35}$ demonstrated that urinary 8-iso-prostaglandin F2 $\alpha$ (8-iso-PGF ${ }_{2 \alpha}$ ) excretion was significantly higher in CBS-deficient patients than in healthy subjects. The metabolite 8-iso-PGF ${ }_{2 \alpha}$ is a member of the F2-isoprostanes, a class of prostanoids that are formed by free radical-mediated oxidation of arachidonic acid. Taken together, these results suggest that lipid peroxidation probably may be caused by increase in free radicals induced by Hcy auto-oxidation.

\section{CONCLUSION}

The results found in this study allowed us to conclude that DNA damage with an oxidative origin occurs in CBS-deficient patients and that NAC has an important in vitro antioxidant effect on DNA damage induced by Hcy. Since homocystinuria is a rare disease, the present results should be confirmed with a large number of patients in a future study evaluating NAC as an adjuvant therapy in CBS deficiency.

\section{Significance of the Study}

According to the results presented in this study, we can suppose that DNA damage by an oxidative mechanism occurs in homocystinuria caused by CBS deficiency, as demonstrated by 8-oxo-7,8-dihydro2 '-deoxyguanosine increased levels in affected patients, a parameter of oxidative damage to DNA, and a protective antioxidant effect of $\mathrm{N}$-acetyl-Lcysteine in this disease, as schematically shown in Figure 4.

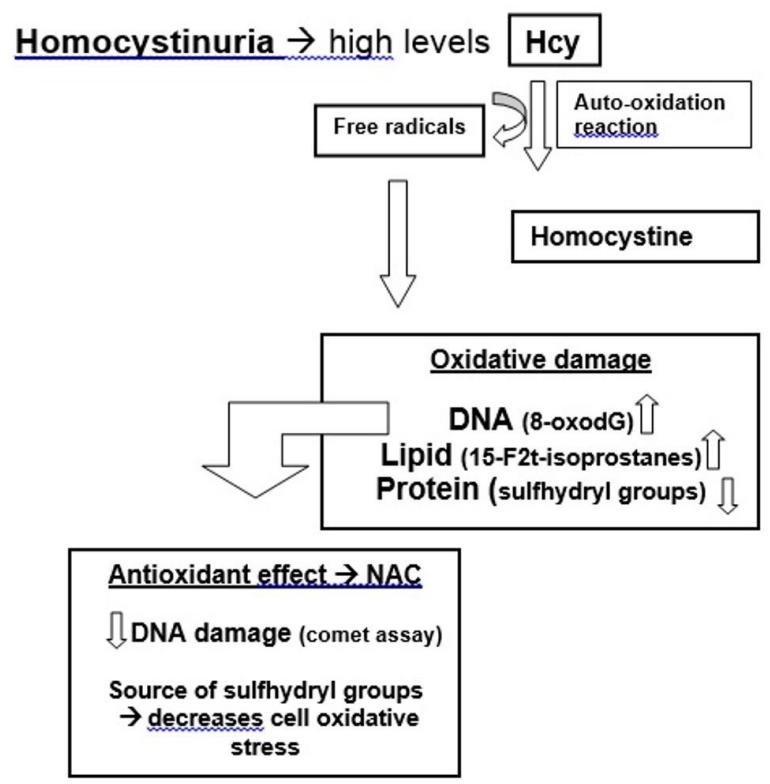

Figure 4: Proposed mechanism of Hcy action on oxidative damage to biomolecules. 


\section{Acknowledgements}

This study was supported in part by grants from CAPES, CNPq and FIPE/HCPA-Brazil. We immensely thank the physicians from the Medical Genetics
Service of Hospital de Clínicas de Porto Alegre for their support, as well as patients and their families.

\section{Conflicts of interest}

The authors declare no conflicts of interest.

\section{REFERENCES}

1. Mudd SH, Levy HL, Kraus JP. Disorders of transsulfuration. In: Scriver CR, Beaudet AL, Sly WS, Valle D, editors. The metabolic and molecular basis of inherited disease. New York: McGraw-Hill; 2001. p. 2007-56.

2. Yap S. Classical homocystinuria: vascular risk and its prevention. J Inherit Metab Dis. 2003;26(23):259-65. http://dx.doi. org/10.1023/A:1024497419821. PMid:12889665.

3. Andria G, Fowler B, Sebastio G. Disorders of sulfur amino acid metabolism. In: Fernandes J, Saudubray JM, Van Den Berghe G, Walter JH, editors. Inborn metabolic diseases, diagnosis and treatment. 4th ed. Würzburg: Springer Medizin Verlag, 2006. p. 273-82. http://dx.doi. org/10.1007/978-3-540-28785-8_21.

4. Vanzin CS, Mescka CP, Donida B, Hammerschimidt T, Ribas GS, Kolling J, et al. Lipid, oxidative and inflammatory profile and alterations in the enzymes paraoxonase and butyrylcholinesterase in plasma of patients with homocystinuria due CBS deficiency: the vitamin B12 and folic acid importance. Cell Mol Neurobiol. 2015;35(6):899-911. http://dx.doi. org/10.1007/s10571-015-0185-7. PMid:25805165.

5. Chowienczyk PJ, Brett SE, Gopaul NK, Meeking D, Marchetti M, RussellJones DL, et al. Oral treatment with an antioxidant (raxofelast) reduces oxidative stress and improves endothelial function in men with type II diabetes. Diabetologia. 2000;43(8):974-7. http://dx.doi. org/10.1007/s001250051478. PMid:10990073.

6. Halliwell B. Lipid peroxidation, antioxidants and cardiovascular disease: how should we move forward? Cardiovasc Res. 2000;47(3):410-8. http://dx.doi. org/10.1016/S0008-6363(00)00097-3. PMid:10963714.
7. Streck EL, Vieira PS, Wannmacher CM, Dutra-Filho CS, Wajner M, Wyse AT. In vitro effect of homocysteine on some parameters of oxidative stress in rat hippocampus. Metab Brain Dis. 2003;18(2):147-54. http:// dx.doi.org/10.1023/A:1023815119931. PMid:12822833.

8. Matté C, Mackedanz V, Stefanello FM, Scherer EB, Andreazza AC, Zanotto C, et al. Chronic hyperhomocysteinemia alters antioxidant defenses and increases DNA damage in brain and blood of rats: protective effect of folic acid. Neurochem Int. 2009;54(1):713. http://dx.doi.org/10.1016/j. neuint.2008.08.011. PMid:18983880.

9. Kruman II, Culmsee C, Chan SL, Kruman Y, Guo Z, Penix L, et al. Homocysteine elicits a DNA damage response in neurons that promotes apoptosis and hypersensitivity to excitotoxicity. J Neurosci. 2000;20(18):6920-6. PMid:10995836.

10. Huang RF, Huang SM, Lin BS, Wei JS, Liu TZ. Homocysteine thiolactone induces apoptotic DNA damage mediated by increased intracellular hydrogen peroxide and caspase 3 activation in HL-60 cells. Life Sci. 2001;68(25):2799-811. http://dx.doi. org/10.1016/S0024-3205(01)01066-9. PMid:11432446.

11. Vanzin CS, Biancini GB, Sitta A, Wayhs CA, Pereira IN, Rockenbach $\mathrm{F}$, et al. Experimental evidence of oxidative stress in plasma of homocystinuric patients: a possible role for homocysteine. Mol Genet Metab. 2011;104(12):112-7. http://dx.doi.org/10.1016/j. ymgme.2011.06.013. PMid:21742526.

12. Vanzin CS, Manfredini $V$, Marinho AE, Biancini GB, Ribas GS, Deon $M$, et al. Homocysteine contribution to DNA damage in cystathionine $\beta$-synthase-deficient patients. Gene. 2014;539(2):270-4. http://dx.doi. org/10.1016/j.gene.2014.02.015. PMid:24534463.
13. Gan W, Nie B, Shi F, Xu XM, Qian JC, Takagi Y, et al. Age-dependent increases in the oxidative damage of DNA, RNA, and their metabolites in normal and senescenceaccelerated mice analyzed by LC-MS/ MS: urinary 8-oxoguanosine as a novel biomarker of aging. Free Radic Biol Med. 2012;52(9):17007. http://dx.doi.org/10.1016/j. freeradbiomed.2012.02.016. PMid:22348977.

14. De Flora S, Balansky R, Bennicelli C, Camoirano A, D'Agostini F, Izzotti A, et al. Mechanisms of anticarcinogenesis: The example of $\mathrm{N}$-acetylcysteine. In: loannides $\mathrm{C}$, Lewis DFV, editors. Drugs, diet and disease, mechanistic approaches to cancer. Hemel Hempstead: Ellis Horwood; 1995. p. 151-203.

15. Magera MJ, Lacey JM, Casetta B, Rinaldo P. Method for the determination of total homocysteine in plasma and urine by stable isotope dilution and electrospray tandem mass spectrometry. Clin Chem. 1999;45(9):1517-22. PMid:10471655.

16. Aksenov MY, Markesbery WR. Changes in thiol content and expression of glutathione redox system genes in the hippocampus and cerebellum in Alzheimer's disease. Neurosci Lett. 2001;302(2-3):141-5. http://dx.doi.org/10.1016/S03043940(01)01636-6. PMid:11290407.

17. Tice RR, Agurell D, Anderson D, Burlinson B, Hartmann A, Kobayashi $\mathrm{H}$, et al. Single cell gel/comet assay: guidelines for in vitro and in vivo genetic toxicology testing. Environ Mol Mutagen. 2000;35(3):20621. http://dx.doi.org/10.1002/ (SICI)1098-2280(2000)35:3<206::AIDEM8>3.0.CO;2-J. PMid:10737956.

18. Hartmann A, Agurell E, Beevers C, Brendler-Schwaab S, Burlinson B, Clay P, et al. Recommendations for conducting the in vivo alkaline Comet assay. 4th International Comet Assay Workshop. Mutagenesis. 
2003;18(1):45-51. http://dx.doi. org/10.1093/mutage/18.1.45. PMid:12473734.

19. Singh NP, McCoy MT, Tice RR, Schneider EL. A simple technique for quantitation of low levels of DNA damage in individual cells. Exp Cell Res. 1988;175(1):184-91. http://dx.doi. org/10.1016/0014-4827(88)90265-0. PMid:3345800.

20. Nadin SB, Vargas-Roig LM, Ciocca DR. A silver staining method for singlecell gel assay. $J$ Histochem Cytochem. 2001;49(9):1183-6. http://dx.doi. org/10.1177/002215540104900912. PMid:11511687.

21. Mc Guire PJ, Parikh A, Diaz GA. Profiling of oxidative stress in patients with inborn errors of metabolism. Mol Genet Metab. 2009;98(1-2):17380. http://dx.doi.org/10.1016/j. ymgme.2009.06.007. PMid:19604711.

22. Lin PY, Yang TH, Lin HG, Hu ML. Synergistic effects of S-adenosylhomocysteine and homocysteine on DNA damage in a murine microglial cell line. Clin Chim Acta. 2007;379(1-2):139-44. http:// dx.doi.org/10.1016/j.cca.2007.01.007. PMid:17300772.

23. Halliwell B, Gutteridge JMC. Free radicals in biology and medicine. 4th ed. Oxford: Oxford University Press; 2007.

24. Cooke MS, Evans MD, Dizdaroglu M, Lunec J. Oxidative DNA damage: mechanisms, mutation, and disease. FASEB J. 2003;17(10):1195-214. http://dx.doi.org/10.1096/fj.02-0752rev. PMid:12832285.
25. Broedbaek K, Weimann A, Stovgaard ES, Poulsen HE. Urinary 8-oxo-7,8dihydro-2'-deoxyguanosine as a biomarker in type 2 diabetes. Free Radic Biol Med. 2011;51(8):14739. http://dx.doi.org/10.1016/j. freeradbiomed.2011.07.007. PMid:21820047.

26. Kobayashi S, Susa T, Tanaka T, Wada Y, Okuda S, Doi M, et al. Urinary 8-hydroxy-2'-deoxyguanosine reflects symptomatic status and severity of systolic dysfunction in patients with chronic heart failure. Eur J Heart Fail. 2011;13(1):29-36. http:// dx.doi.org/10.1093/eurjhf/hfq178. PMid:20965876.

27. De Flora S, Izzotti A, D'Agostini F, Balansky RM. Mechanisms of $\mathrm{N}$-acetylcysteine in the prevention of DNA damage and cancer, with special reference to smokingrelated end-points. Carcinogenesis. 2001;22(7):999-1013. http://dx.doi. org/10.1093/carcin/22.7.999. PMid:11408342.

28. Bajt ML, Knight TR, Lemasters JJ, Jaeschke H. Acetaminopheninduced oxidant stress and cell injury in cultured mouse hepatocytes: protection by $\mathrm{N}$-acetylcysteine. Toxicol Sci. 2004;80(2):343-9. http:// dx.doi.org/10.1093/toxsci/kfh151. PMid:15115886.

29. Ozdemir ZC, Koc A, Aycicek A, Kocyigit A. N-Acetylcysteine supplementation reduces oxidative stress and DNA damage in children with $\beta$-thalassemia. Hemoglobin. 2014;38(5):359-64. http://dx.doi.or g/10.3109/03630269.2014.951890. PMid:25222041.
30. Yang Q, Shi L, Huang K, Xu W. Protective effect of $\mathrm{N}$-acetylcysteine against DNA damage and S-phase arrest induced by ochratoxin $A$ in human embryonic kidney cells (HEK293). Food Chem Toxicol. 2014;70:407. http://dx.doi.org/10.1016/j. fct.2014.04.039. PMid:24799199.

31. Marchetti DP, Donida B, Rosa HT, Manini PR, Moura DJ, Saffi J, et al. Protective effect of antioxidants on DNA damage in leukocytes from X-linked adrenoleukodystrophy patients. Int J Dev Neurosci. 2015;43:8-15. http://dx.doi. org/10.1016/j.ijdevneu.2015.03.004. PMid:25765338.

32. Roberts LJ, Morrow JD. Measurement of F2-isoprostanes as an index of oxidative stress in vivo. Free Radic Biol Med. 2001;28:65-73.

33. Starkebaum G, Harlan JM. Endothelial cell injury due to coppercatalyzed hydrogen peroxide generation from homocysteine. $J$ Clin Invest. 1986;77(4):1370-6. http://dx.doi.org/10.1172/JCl112442. PMid:3514679.

34. Loscalzo J. The oxidant stress of hyperhomocyst(e)inemia. J Clin Invest. 1996;98(1):5-7. http:// dx.doi.org/10.1172/JCl118776. PMid:8690803.

35. Davì G, Di Minno G, Coppola A, Andria G, Cerbone AM, Madonna $\mathrm{P}$, et al. Oxidative stress and platelet activation in homozygous homocystinuria. Circulation. 2001;104(10):1124-8. http://dx.doi. org/10.1161/hc3501.095287. PMid:11535567. 